\title{
Design and Development of a Mixed-Mode Domestic Solar Dryer
}

\author{
Ikechukwu Celestine Ugwuoke ${ }^{\mathrm{a},{ }^{*}}$, Ibukun Blessing Ikechukwu $^{\mathrm{b}}$, Ogbe Eric Ifianyi ${ }^{\mathrm{c}}$ \\ ${ }^{a, c}$ Department of Mechanical Engineering, Federal University of Technology Minna, Niger State, Nigeria \\ ${ }^{b}$ Department of Agricultural and Bioresources Engineering, Federal University of Technology Minna, Niger \\ State, Nigeria
}

Received: 09 November 2018; Accepted: 15 February 2019; Published: 08 May 2019

\begin{abstract}
This work focuses on the design and development of a mixed-mode domestic solar dryer in which the slices of pepper, okra and yam were dried simultaneously by both direct radiation through the transparent glass roof of the drying chamber and by the heated air from the solar collector. The dryer was made up of the solar collector, the desiccant chamber and the drying chamber which contains a rack of three trays. The air comes in through the air inlet and heated up within the solar collector and then channeled through the drying chamber by natural convection where it is utilized for drying purposes. The development was done using locally sourced and readily available materials such as wood, transparent glass sheet, mild steel metal sheet, mosquito galvanized wire mesh and chicken galvanized wire mesh. The maximum temperature attained by the solar collector, drying chamber during test were $69^{\circ} \mathrm{C}$ and $55^{\circ} \mathrm{C}$ respectively, with a corresponding ambient temperature of $39^{\circ} \mathrm{C}$. The mass of water removal of $43 \mathrm{~g}, 136 \mathrm{~g}$ and $255 \mathrm{~g}$ from pepper, okra and yam slices respectively was achieved making use of the passive solar food dryer as against the water removal of $39 \mathrm{~g}, 126 \mathrm{~g}$ and $218 \mathrm{~g}$ from pepper, okra and yam slices respectively achieved using the sun drying method which indicates a difference of $4 \mathrm{~g}, 10 \mathrm{~g}$ and $37 \mathrm{~g}$ for pepper, okra and yam slices respectively. The rapid rate of drying achieved with the use of this dryer shows that it has the ability to dry food items rapidly to an acceptable moisture content level.
\end{abstract}

Index Terms: Mixed-mode, domestic, solar dryer, solar collector, drying chamber.

(C) 2019 Published by MECS Publisher. Selection and/or peer review under responsibility of the Research Association of Modern Education and Computer Science.

\section{Introduction}

Drying is one of the oldest methods of food preservation [1.15]. Traditionally, drying is carried out openly in the field. Open air drying using direct sunlight has numerous draw backs which include subjection to adverse

* Corresponding author.

E-mail address: 
weather conditions like rain, dusts, wind, insects and sometimes rodents. This ultimately slows down the drying rate, causing mold formation. For several thousand years, people have been preserving dates, figs, apricots, grapes, herbs, potatoes, corn, milk, meat, and fish by drying [4,17]. Until canning was developed at the end of the 18th century, drying was virtually the only method of food preservation. Open sun drying has no quality control and also has a risk of contamination, creating a potential health hazard. The product's quality is seriously degraded, sometimes to the extent that they are inedible [17,3,12]. Food deterioration and spoilage is caused by the action of yeasts, bacteria, and enzymes. The drying process removes enough moisture from food to greatly decrease these destructive effects. Food drying can reduce loss of a harvest surplus, allow storage for food shortages, and in some cases facilitate export to high value markets. To guide against the aforementioned disadvantages and also to speed up the rate of drying the produce, control the final moisture content and elimination of bacterial effect, various types of solar dehydrators can be used [18]. With subsequent development in the technical world, efforts are focused towards improve drying and this led to solar drying as an upgrade from sun drying.

Solar dehydrators are special drying enclosure that is used to dry food produce and has numerous advantages which include controlled drying rate, drying at a higher temperature, lower relative humidity, and reduced moisture content of dried food. Also it protects the produce against adverse weather conditions, pests and rodents. In many parts of the world there is a growing awareness that renewable energy has an important role to play in extending technology to the farmer in developing countries to increase their productivity [16]. In order to improve traditional drying, solar dryers which have the potential of substantially reducing the disadvantages of open air drying; have received considerable attention over the past 20 years $[2,8,7,12,1,15]$. Currently, several solar dehydrator designs exist on the market, and most of these designs require expensive materials and source of energy, which makes the prototype expensive and difficult to obtain for small scale producers $[10,12]$. This work focuses on the design and development of a mixed-mode solar dryer for domestic purpose.

\section{Materials and Design Calculations}

\subsection{Materials}

The following materials were used for the development of the passive food solar dryer:

a. Wood for the housing of the entire system; wood was preferred being a very good insulator and relatively cheaper than metals.

b. Transparent Glass (4mm thick) for the solar collector and the drying chamber cover plate. It allows into the system solar radiation but resists the outflow of heat energy from the system. The solar collector is the part of the solar dryer responsible for heating up the air used for drying purpose. It consists of the cover plate, absorber plate and insulator. The drying chamber which has dimensions $70 \mathrm{~cm} \times 60 \mathrm{~cm} \times 80 \mathrm{~cm}$ is where the actual drying takes place. It is made of wood with the outer surface painted black. It has three layers with each having a drying tray. The drying tray is made up of a wooden frame and a chicken galvanized wire mesh.

c. Insulator to minimize the heat loss from the solar collector. Styrofoam as insulator is capable of withstanding heat and also fire resistant.

d. Mild steel sheet ( $1 \mathrm{~mm}$ thick) for the absorber plate. The absorber plate is the plate used as the base of the solar collector. It is painted black so as to convert solar radiation entering the system into heat energy which helps to heat up the air entering the system

e. Perforated mild steel sheet (1mm thick) as a separator of the drying chamber from the desiccant chamber. It also allows for even distribution of heated air. The purpose of the desiccant chamber is to reduce the relative humidity of air.

f. Mosquito galvanized wire mesh for covering the air inlet and outlet so as to prevent insects and rodents from entering the system. 
g. Nails and glue as fasteners and adhesives.

h. Hinges and handle for the dryer door.

i. Black Paint for the solar collector absorber plate and the exterior of the dryer structure.

j. Chicken galvanized wire mesh for drying trays where what is to be dried are kept

\subsection{Determination of the Tilting Angle for the Solar Collector}

The tilting angle for the solar collector was determined from [14]:

$\beta=10^{\circ}+\operatorname{Lat} \Phi$

Where,

$\beta=$ Tilting angle

Lat $\Phi=$ Latitude angle of the solar collector location

The latitude angle of Minna where the dryer was designed and developed is $9.39^{\circ} \mathrm{N}$, substituting into equation (1) gives

$$
\beta=10^{\circ}+9.39^{\circ}=19.39^{\circ}
$$

The flat-plate solar collector is normally tilted and oriented in such a way that it receives maximum solar radiation in the desired season of use. The best stationary orientation is due south in the northern hemisphere and due north in southern hemisphere. The solar collector for this work was therefore oriented facing the south and tilted at $19.39^{\circ}$ to the horizontal.

\subsection{Determination of Total Solar Radiation Incident on the Absorber Surface}

The total solar radiation incident on the absorber surface was determined from [11]:

$I_{T}=H \times R$

Where,

$I_{T}=$ Total solar radiation incident on the absorber surface $\left(\mathrm{W} / \mathrm{m}^{2}\right)$

$H=$ Average daily solar radiation on horizontal surface

$R=$ Average effective ratio of solar energy on the tilted surface to that on the horizontal surface $=1.0035$.

\subsection{Determination of Useful Energy Gained by the Collector}

The useful energy gained by the collector was determined from [7]:

$\mathcal{Q}_{u}=\alpha \tau I_{T}-U_{L}\left(T_{C}-T_{A}\right)$

Where,

$Q_{u}=$ Useful energy gained by the collector $\left(\mathrm{W} / \mathrm{m}^{2}\right)$

$\alpha=$ Absorption 
$\tau=$ Glass transmittance $=0.9$

$U_{L}=$ Overall heat transfer coefficient of the absorber $\left(\mathrm{W} / \mathrm{m}^{2} / \mathrm{K}\right)$

$T_{C}=$ Temperature of the collector absorber $(\mathrm{K})$

$T_{A}=$ Ambient air temperature $(\mathrm{K})$

\subsection{Determination of the Volume Flow Rate of Air in the Collector}

The volume flow rate of air in the collector was determined from:

$\dot{V}=v_{a} A_{a g}=v_{a} h_{a g} w_{a g}$

$\dot{V}=$ Volume flow rate of air $\left(\mathrm{m}^{3} / \mathrm{s}\right)$

$A_{a g}=$ Air gap area $\left(\mathrm{m}^{2}\right)$

$v_{a}=$ Velocity of air $(\mathrm{m} / \mathrm{s})=0.15 \mathrm{~m} / \mathrm{s}$

$h_{a g}=$ Air gap height $(\mathrm{m})=0.056 \mathrm{~m}$

$w_{a g}=$ Air gap width $(\mathrm{m})=0.60 \mathrm{~m}$

\subsection{Determination of the mass flow rate of air in the collector}

The mass flow rate of air in the collector was determined from:

$\dot{M}_{a}=\dot{V} \rho$

Where,

$\dot{M}_{a}=$ Mass flow rate of air $(\mathrm{kg} / \mathrm{s})$

$\rho=$ Density of air $\left(\mathrm{kg} / \mathrm{m}^{3}\right)=1.225 \mathrm{~kg} / \mathrm{m}^{3}$ at STP

\subsection{Determination of Collector Surface Area}

The collector surface area was determined from:

$A_{C}=\frac{\dot{M}_{a} C_{P}\left(T_{C}-T_{A}\right)}{I_{T}}$

Where,

$A_{C}=$ Collector surface area $\left(\mathrm{m}^{2}\right)$

$C_{P}=$ Specific heat capacity of air at constant pressure $(\mathrm{J} / \mathrm{kg} / \mathrm{K})=1000 \mathrm{~J} / \mathrm{kg} / \mathrm{K}$

\subsection{Determination of Collector Length}

The collector length was determined from:

$L_{C}=\frac{A_{C}}{w_{a g}}$

Where, 
$L_{C}=$ Collector length $(\mathrm{m})$

\subsection{Determination of the Insulator base Thickness for the Collector}

For the design, the thickness of the insulator was taken as 6 to $8 \mathrm{~cm}$. The side of the solar collector was made of finished wood, the loss of heat and emittance through the side of the collector will be considered negligible.

\subsection{Determination of Collector Efficiency}

The collector efficiency was determined from [5]:

$\eta_{C}=\frac{\rho C_{P} \dot{V}\left(T_{C}-T_{A}\right)}{A_{C} I_{T}} \times 100$

Where,

$\eta_{C}=$ Collector efficiency $(\%)$

\subsection{Determination of Dryer Efficiency}

The dryer efficiency was determined from $[9,5]$ :

$\eta_{d}=\frac{M L_{V}}{A_{C} T_{T} t} \times 100$

Where,

$\eta_{d}=$ Dryer efficiency $(\%)$

$M=$ Mass of evaporated moisture $(\mathrm{kg})$

$L_{V}=$ Latent heat of vaporization of water $(\mathrm{J} / \mathrm{kg})$

$t=$ Time of drying (s)

\subsection{Determination of Moisture Content}

The moisture content on percentage wet basis was determined from $[5,6,13]$ :

$M C=\frac{M_{i}-M_{f}}{M_{i}} \times 100$

Where,

$M C=$ Moisture content $(\%)$

$M_{i}=$ Mass of sample before drying $(\mathrm{g})$

$M_{f}=$ Mass of sample after drying $(\mathrm{g})$

\section{Testing of the Solar Dryer}

The testing of the solar dryer shown in Figure 1 was done in the month of March in Minna, a city in Nigeria on latitude $9.39^{\circ}$. The dryer was placed outside with the solar collector facing the sun. Three tests were carried 
out to evaluate the performance of the solar dryer. Firstly, for the no load test, the temperature of the heated air inside the solar collector and the drying chamber, together with the ambient temperature of the air was taken every one hour interval, starting from $9 \mathrm{am}$ to $6 \mathrm{pm}$. In the absence of a hygrometer, two thermometers were used to measure the relative humidity. One of the thermometer has its sensor whirled with a wick, with the wick touching water in a beaker to get the wet bulb temperature, the other thermometer provided the normal temperature which gives the dry bulb temperature. The wet bulb and dry bulb temperature were used to obtain the relative humidity on the psychometric chart, which was done every one hour interval from $9 \mathrm{am}$ to $6 \mathrm{pm}$. A clinical thermometer was used for the temperature measurement in the solar dryer, and the variation in weight loss was done using an electronic weighing scale. The maximum temperatures obtained for the solar collector, drying chamber and ambient were $69^{\circ} \mathrm{C}, 55^{\circ} \mathrm{C}$ and $39^{\circ} \mathrm{C}$ respectively. Secondly, tests were carried out to determine the drying rate of pepper, okra and yam. The drying chamber was loaded with the pepper, okra and yam (sliced to about $1 \mathrm{~cm}$ and blanched) estimated to weigh averagely $80 \mathrm{~g}, 190 \mathrm{~g}$ and $310 \mathrm{~g}$ respectively. Thirdly, the results obtained from the solar dryer were compared with that obtained from sun drying.

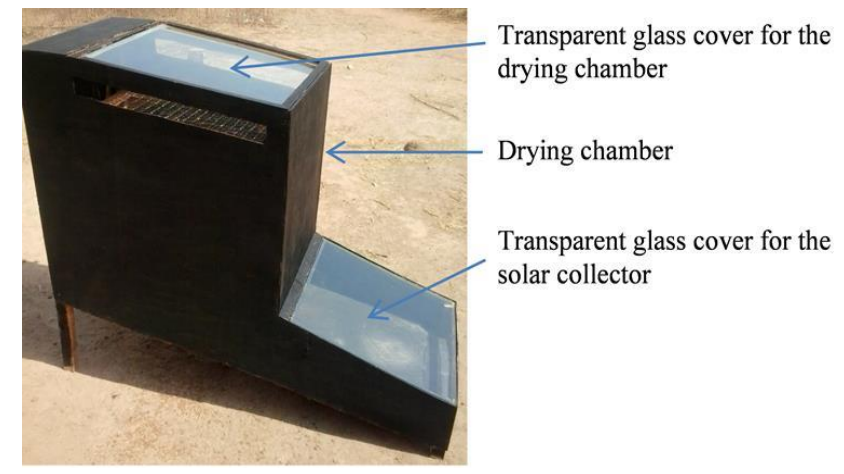

Fig.1. Constructed Mixed-mode Solar Dryer

\section{Results and Discussion}

Table 1 show the result of variations of temperature with time within the dryer. The solar dryer generated the most heat when the sun is over-head during mid-day, which resulted in very high temperatures within the solar collector and the drying chamber as compared to the ambient temperature as indicated in Table 1 . This signifies that the solar dryer performance and efficiency will improve significantly when compared with that of sun drying. Table 2 show the result of variations of relative humidity with time within the dryer. Comparison of Table 1 and Table 2 shows that the process of drying using the solar dryer was greatly enhanced by the heated air at very low humidity.

Table 1. Result of Variations of Temperature with time Within the Dryer

\begin{tabular}{llcl}
\hline $\begin{array}{l}\text { Time } \\
\text { (hours) }\end{array}$ & Ambient Temperature $\left({ }^{\circ} \mathrm{C}\right)$ & Collector Temperature $\left({ }^{\circ} \mathrm{C}\right)$ & $\begin{array}{l}\text { Drying } \\
\text { Temperature }\left({ }^{\circ} \mathrm{C}\right)\end{array}$ \\
\hline 9.00 & 26.00 & 54.00 & 41.00 \\
10.00 & 29.00 & 58.00 & 46.00 \\
11.00 & 32.00 & 61.00 & 48.00 \\
12.00 & 34.00 & 63.00 & 49.00 \\
13.00 & 38.00 & 69.00 & 54.00 \\
14.00 & 39.00 & 69.00 & 55.00 \\
15.00 & 35.00 & 68.00 & 54.00 \\
16.00 & 31.00 & 65.00 & 51.00 \\
17.00 & 32.00 & 60.00 & 47.00 \\
18.00 & 30.00 & 56.00 & 43.00 \\
\hline
\end{tabular}


Table 2. Result of Variations of Relative Humidity with time Within the Dryer

\begin{tabular}{|c|c|c|}
\hline $\begin{array}{l}\text { Time } \\
\text { (hours) }\end{array}$ & $\begin{array}{ll}\text { Ambient } & \text { Relative } \\
\text { Humidity (\%) } & \end{array}$ & $\begin{array}{l}\text { Drying Chamber Relative Humidity } \\
(\%)\end{array}$ \\
\hline 9.00 & 65.00 & 81.00 \\
\hline 10.00 & 41.00 & 81.00 \\
\hline 11.00 & 32.00 & 80.00 \\
\hline 12.00 & 30.00 & 79.00 \\
\hline 13.00 & 31.00 & 78.00 \\
\hline 14.00 & 32.00 & 77.00 \\
\hline 15.00 & 32.50 & 78.00 \\
\hline 16.00 & 38.00 & 79.00 \\
\hline 17.00 & 42.00 & 79.00 \\
\hline 18.00 & 48.00 & 80.00 \\
\hline
\end{tabular}

Table 3. Daily Moisture Loss for Pepper Sample using Solar Dryer

\begin{tabular}{|c|c|c|c|c|c|c|}
\hline Day & $\begin{array}{l}\text { Initial mass } \mathrm{M}_{i} \\
(\mathrm{~g})\end{array}$ & $\begin{array}{l}\begin{array}{l}\text { Final mass } \\
(\mathrm{g})\end{array} \\
\mathrm{M}_{f}\end{array}$ & $\begin{array}{l}\text { Moisture loss } \\
(\mathrm{g})\end{array}$ & $\begin{array}{l}\text { Moisture content } \\
(\%)\end{array}$ & $\begin{array}{l}\text { Ambient Temp. } \\
\left({ }^{\circ} \mathrm{C}\right)\end{array}$ & Dryer Temp. $\left({ }^{\circ} \mathrm{C}\right)$ \\
\hline 1 & 80.00 & 70.00 & 10.00 & 12.5 & 38.00 & 54.00 \\
\hline 2 & 68.00 & 62.00 & 6.00 & 8.82 & 39.00 & 55.00 \\
\hline 3 & 57.00 & 52.00 & 5.00 & 8.77 & 40.00 & 52.00 \\
\hline 4 & 49.00 & 44.50 & 3.50 & 7.14 & 38.00 & 54.00 \\
\hline 5 & 42.50 & 37.00 & 5.50 & 12.16 & 39.00 & 55.00 \\
\hline
\end{tabular}

Table 4. Daily Moisture Loss for Pepper Sample using sun Drying

\begin{tabular}{|c|c|c|c|c|c|c|}
\hline Day & $\begin{array}{lll}\begin{array}{l}\text { Initial mass } \\
(\mathrm{g})\end{array} & \mathrm{M}_{i} \\
\end{array}$ & $\begin{array}{l}\begin{array}{l}\text { Final mass } \\
(\mathrm{g})\end{array} \\
\mathrm{M}_{f}\end{array}$ & $\begin{array}{l}\text { Moisture loss } \\
(\mathrm{g})\end{array}$ & $\begin{array}{l}\text { Moisture content } \\
(\%)\end{array}$ & $\begin{array}{l}\text { Drying } \\
\left({ }^{\circ} \mathrm{C}\right)\end{array}$ & Temp. \\
\hline 1 & 80.00 & 74.00 & 6.00 & 7.50 & 40.00 & \\
\hline 2 & 72.00 & 66.00 & 6.00 & 8.33 & 39.00 & \\
\hline 3 & 61.00 & 56.00 & 5.00 & 8.19 & 39.00 & \\
\hline 4 & 53.00 & 48.50 & 4.50 & 8.49 & 38.00 & \\
\hline 5 & 46.50 & 41.00 & 5.50 & 11.82 & 39.00 & \\
\hline
\end{tabular}

Table 3 and 4 shows the masses of samples of pepper considered and their initial and final masses, which was used to determine the moisture loss in grams of the samples from day 1 when they were placed in the drying chamber to day 5 and the daily moisture content on percentage wet basis of the pepper slices. The result show a total moisture loss of $43 \mathrm{~g}$ using solar dryer and $39 \mathrm{~g}$ using sun drying method.

Table 5. Daily Moisture Loss for Okra Sample using Solar Dryer

\begin{tabular}{|c|c|c|c|c|c|c|}
\hline Day & $\begin{array}{l}\text { Initial mass } \mathrm{M}_{i} \\
(\mathrm{~g})\end{array}$ & $\begin{array}{l}\begin{array}{l}\text { Final mass } \\
(\mathrm{g})\end{array} \\
\mathrm{M}_{f}\end{array}$ & $\begin{array}{l}\text { Moisture loss } \\
\text { (g) }\end{array}$ & $\begin{array}{l}\text { Moisture content } \\
(\%)\end{array}$ & $\begin{array}{l}\text { Ambient Temp. } \\
\left({ }^{\circ} \mathrm{C}\right)\end{array}$ & Dryer Temp. $\left({ }^{\circ} \mathrm{C}\right)$ \\
\hline 1 & 190.00 & 144.00 & 46.00 & 24.21 & 38.00 & 52.00 \\
\hline 2 & 132.00 & 110.00 & 22.00 & 16.66 & 39.00 & 53.00 \\
\hline 3 & 102.00 & 84.00 & 18.00 & 17.64 & 37.00 & 56.00 \\
\hline 4 & 80.00 & 66.00 & 14.00 & 17.5 & 40.00 & 55.00 \\
\hline 5 & 61.00 & 54.00 & 7.00 & 11.47 & 40.00 & 54.00 \\
\hline
\end{tabular}


Table 6. Daily Moisture Loss for Okra Sample using sun drying

\begin{tabular}{llllll}
\hline Day & Initial mass $\mathrm{M}_{i}(\mathrm{~g})$ & Final mass $\mathrm{M}_{f}(\mathrm{~g})$ & Moisture loss $(\mathrm{g})$ & Moisture content $(\%)$ & Drying Temp. $\left({ }^{\circ} \mathrm{C}\right)$ \\
\hline 1 & 190.00 & 144.00 & 46.00 & 24.21 & 34.00 \\
2 & 124.00 & 110.00 & 14.00 & 11.29 & 36.00 \\
3 & 101.00 & 91.00 & 10.00 & 9.90 & 37.00 \\
4 & 86.00 & 76.00 & 10.00 & 11.62 & 35.00 \\
5 & 75.00 & 64.00 & 11.00 & 14.66 & 39.00 \\
\hline
\end{tabular}

Table 5 and 6 shows the masses samples of okra slices considered and their initial and final masses, which was used to determine the moisture loss in grams of the samples from day 1 when they were placed in the drying chamber to day 5 and the daily moisture content on percentage wet basis of the okra slices. The result show a total moisture loss of $136 \mathrm{~g}$ using solar dryer and 126g using sun drying method. Table 7 and 8 shows the masses of samples of yam slices considered and their initial and final masses, which was used to determine the moisture loss in grams of the samples from day 1 when they were placed in the drying chamber to day 5 and the daily moisture content on percentage wet basis of the yam slices. The result show a total moisture loss of $255 \mathrm{~g}$ using solar dryer and $218 \mathrm{~g}$ using sun drying method. Figure 2 and 3 shows the dried samples of pepper, okra, and yam slices using the solar dryer and under the sun. The drying rate was observed to increase continuously between $9.00 \mathrm{~h}$ and $3.00 \mathrm{~h}$ but decreased slowly thereafter. This shows earlier and faster removal of moisture from the dried items in the drying chamber. The appearance of the pepper, okra and yam slices as captured in Figure 2 and 3 reveals uniform and better drying in passive solar drying as compared with sun drying. Table 9 gives some of the values of the evaluated parameters of the dryer.

Table 7. Daily Moisture Loss for Yam Sample using Solar Dryer

\begin{tabular}{|c|c|c|c|c|c|c|}
\hline Day & $\begin{array}{lll}\begin{array}{l}\text { Initial mass } \\
(\mathrm{g})\end{array} & \mathrm{M}_{i} \\
\end{array}$ & $\begin{array}{l}\text { Final mass } \mathrm{M}_{f} \\
(\mathrm{~g})\end{array}$ & $\begin{array}{l}\text { Moisture loss } \\
(\mathrm{g})\end{array}$ & $\begin{array}{l}\text { Moisture content } \\
(\%)\end{array}$ & $\begin{array}{ll}\text { Ambient } & \text { Temp. } \\
\left({ }^{\circ} \mathrm{C}\right) & \end{array}$ & Dryer Temp. $\left({ }^{\circ} \mathrm{C}\right)$ \\
\hline 1 & 310.00 & 249.00 & 61.00 & 19.67 & 38.00 & 46.00 \\
\hline 2 & 200.00 & 167.00 & 33.00 & 16.50 & 37.00 & 43.00 \\
\hline 3 & 135.00 & 109.00 & 26.00 & 19.25 & 34.00 & 45.00 \\
\hline 4 & 92.00 & 73.00 & 19.00 & 20.65 & 35.00 & 47.00 \\
\hline 5 & 69.00 & 55.00 & 14.00 & 20.28 & 34.00 & 46.00 \\
\hline
\end{tabular}

Table 8. Daily Moisture Loss for Yam Sample using sun drying

\begin{tabular}{llllll}
\hline Day & Initial mass $\mathrm{M}_{i}(\mathrm{~g})$ & Final mass $\mathrm{M}_{f}(\mathrm{~g})$ & Moisture loss $(\mathrm{g})$ & Moisture content $(\%)$ & Drying Temp. $\left({ }^{\circ} \mathrm{C}\right)$ \\
\hline 1 & 310.00 & 252.00 & 58.00 & 18.71 & 36.00 \\
2 & 204.00 & 174.00 & 30.00 & 12.50 & 35.00 \\
3 & 144.00 & 123.00 & 21.00 & 14.58 & 34.00 \\
4 & 126.00 & 114.00 & 12.00 & 9.52 & 36.00 \\
5 & 101.00 & 92.00 & 9.00 & 8.91 & 37.00 \\
\hline
\end{tabular}




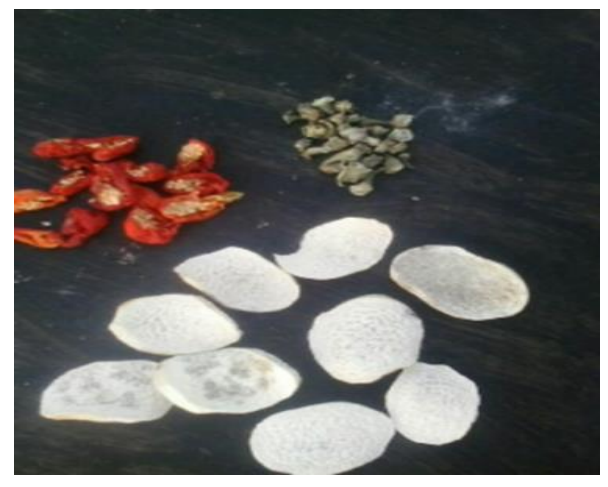

Fig.2. Sun Dried Yam, Pepper and Okra Slices

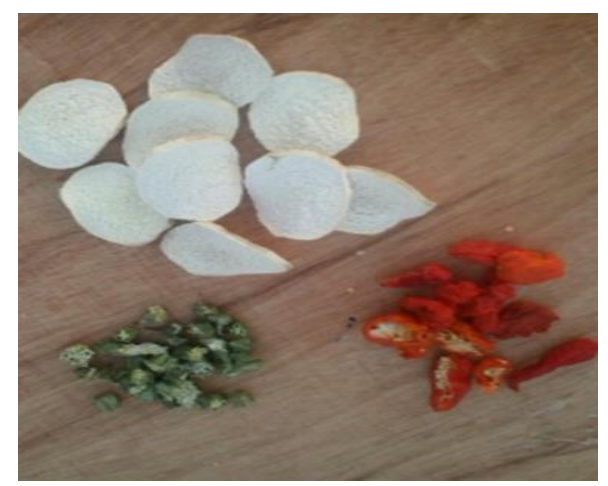

Fig.3. Solar Dried Yam, Pepper and Okra Slices

Table 9. Evaluated Parameters of the Dryer

\begin{tabular}{ll}
\hline Parameter & Values obtained \\
\hline$\beta$ & $19.39^{\circ}$ \\
$I_{T}$ & $956.11 \mathrm{~W} / \mathrm{M}^{2}$ \\
$A_{C}$ & $0.36 \mathrm{~m}^{2}$ \\
$\eta_{C}$ & $37.9 \%$ (average) \\
\hline
\end{tabular}

\section{Conclusions}

The following conclusions are made from the test carried out: The solar dryer raises the ambient air temperature to a considerable high value which absorbs moisture content in food faster and thus, increasing the drying rate of food; The product/food inside the solar dryer's drying chamber requires lesser frequent attention compare with those in the open air/sun drying in order to prevent attack of the food produce by rain or rodents (both human and animals); The dryer was used to dry yam perfectly and can be used to dry cassava; The monitoring was done with relative ease when compared to the sun drying technique; The capital cost involved in the construction of a passive solar dryer is much lower to that of active/mechanical dryer; The mass of water removal of $43 \mathrm{~g}, 136 \mathrm{~g}$ and $255 \mathrm{~g}$ in pepper, okra and yam slices respectively using the passive solar dryer was achieved as against $39 \mathrm{~g}, 126 \mathrm{~g}$ and $218 \mathrm{~g}$ in pepper, okra and yam slices using the sun drying method. 


\section{References}

[1] Abdullahi Y, Momoh M, Garba MM, Musa M. Design and Construction of an Adjustable and Collapsible Natural Convection Solar Food Dryer. International Journal of Computational Engineering Research 2013; 3(6), 1-8.

[2] Bassey MW. Development and use of solar drying technologies, Nigerian Journal of Solar Energy 1989; 133-164.

[3] Diamante LM, Munro PA. Mathematical Modelling of Thin Layer Solar Drying of Sweet Potatoes, Solar Energy 2004; (51), 176 - 271.

[4] Ekechukwu OV, Norton B. Review of Solar Energy Drying Systems iii: Low Temperature Air-Heating Solar Collector for Drying Application, Energy Conversion and Management 1999; 40, 615-655.

[5] Ezekoye BA, Enebe OM. Development and Performance Evaluation of Modified Integrated Passive Solar Grain Dryer, Pacific Journal of Science and Technology 2006; 7(2), 185- 190.

[6] Forson FK, Nazha MAA, Akuffo FO, Rajakaruna H. Design of Mixed-Mode Natural Convection Solar Crop Dryers: Application of principles and rules of thumb. Renewable Energy Journal 2007; 32.

[7] Gatea AA. Design, construction and performance evaluation of solar maize dryer. Journal of Agricultural Biotechnology and Sustainable Development 2010; 2(3), 39-46.

[8] Irtwange SV, Adebayo S. Development and Performance of a Laboratory-Scale Passive Solar Grain Dryer. Journal of Agricultural Extension and Rural Development 2009; 1(2), 42-49.

[9] Itodo IN, Obetta SE, Satimehin AA. Evaluation of a solar crop dryer for rural applications in Nigeria. Botswana J. Technol. 2002; 11(2), 58-62.

[10] Nejat TV. Alternative Energy Sources viii, Hemisphere Publishing Company 1989; 1

[11] Olaloye DO. (2008), The Design and Construction of Solar Incubator, Project Report Submitted to the Department of Mechanical Engineering, University of Agriculture, Aboekuta.

[12] Raju RVS, Reddy RM, Reddy ES. Design and Fabrication of Efficient Solar Dryer. International Journal of Engineering Research and Applications 2013; 3(6), 1445-1458.

[13] Senger SH, Khandetod YP, Mohod AG. Low Cost Solar Dryer for Fish. African Journal of Environmental Science and Technology 2009; 3(9), 265-271.

[14] Sukhatme SP. Solar Energy Principles of Thermal Collection and Storage. Tata McGraw Hill Publishing Company Limited 1996.

[15] Umogbai VI, Iorter HA. Design, construction and performance evaluation of a passive solar dryer for maize cobs. African Journal of Food Science and Technology 2013; 4(5), 110-115.

[16] Waewsak J, Chindaruksa S, Punlek C. A mathematical modeling study of hot air drying for some agricultural products. Thammasat International Journal of Science and Technology 2006, 11(1), 14 - 20.

[17] Whitefield DE. Solar Dryer Systems and Internet, Important Resources to Improve Food Preparation. Proceedings of International Conference on Solar Cooking, Kimberly, South Africa 2000.

[18] Yaldiz O, Ertekin C, Uzun HB. Mathematical modelling of thin layer solar drying of sultana grapes. Energy 2001; 26, 457-465.

\section{Authors' Profiles}

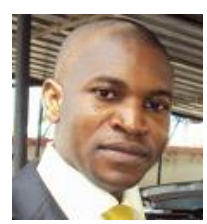

Ikechukwu Celestine UGWUOKE is currently a Senior Lecturer in the Department of Mechanical Engineering, Federal University of Technology, Minna, Nigeria. His area of research interest is in Mechanical Engineering Design and Solid Mechanics. He holds a PhD degree in Mechanical Engineering, Design and Solid Mechanics Option. 
Ibukun Blessing Ikechukwu holds a B.Eng. degree in Agricultural and Bio-resources Engineering, Federal University of Technology, Minna, Nigeria.

Ogbe Eric Ifianyi holds a B.Eng. degree in Mechanical Engineering, Federal University of Technology, Minna, Nigeria.

How to cite this paper: Ikechukwu Celestine Ugwuoke, Ibukun Blessing Ikechukwu, Ogbe Eric Ifianyi,"Design and Development of a Mixed-Mode Domestic Solar Dryer", International Journal of Engineering and Manufacturing(IJEM), Vol.9, No.3, pp.55-65, 2019.DOI: 10.5815/ijem.2019.03.05 